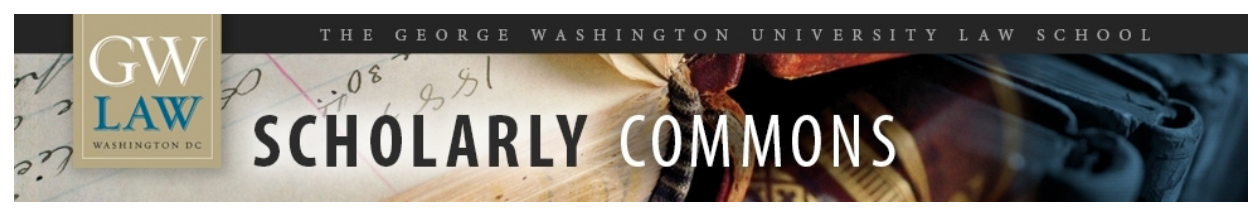

\title{
Worker Participation and Social Dialogue at the Work Place Level in the United States
}

Charles B. Craver

George Washington University Law School, ccraver@law.gwu.edu

Follow this and additional works at: https://scholarship.law.gwu.edu/faculty_publications

Part of the Law Commons

\section{Recommended Citation}

Craver, Charles B., "Worker Participation and Social Dialogue at the Work Place Level in the United States" (2008). GW Law Faculty Publications \& Other Works. 466.

https://scholarship.law.gwu.edu/faculty_publications/466

This Article is brought to you for free and open access by the Faculty Scholarship at Scholarly Commons. It has been accepted for inclusion in GW Law Faculty Publications \& Other Works by an authorized administrator of Scholarly Commons. For more information, please contact spagel@law.gwu.edu. 


\title{
WORKER REPRESENTATION AND SOCIAL DIALOGUE AT THE WORK PLACE LEVEL IN THE UNITED STATES
}

\author{
Charles B. Craver, U.S. Reporter \\ Freda Alverson Professor of Law \\ George Washington University
}

[W] e must have democracy in industry as well as in government; . . . democracy in industry means fair participation by those who work in the decisions vitally affecting their lives and livelihood; and . . . the workers in our great . . . industries can enjoy this participation only if allowed to organize and bargain collectively through representatives of their own choosing. ${ }^{1}$

Approaching the twenty-first century, the United States effectively stands alone among the developed nations, on the verge of having no effective system of worker representation and consultation. ... . Survey data indicate that some 30 to 40 million American workers without union representation desire such representation, and some 80 million workers, many of whom do not approve of unions, desire some independent collective voice in their workplace. ${ }^{2}$

\section{INTRODUCTION}

Individual workers in the United States possess minimal employment rights compared to other advanced nations. Almost all are employed on an at-will basis, which means that they can be terminated at any time for almost any reason. ${ }^{3}$ Private sector employees enjoy no constitutional rights vis-à-vis their employers due to the absence of government involvement. ${ }^{4}$ The primary exceptions to this rule are provided by civil

\footnotetext{
${ }^{1}$ Senator Robert Wagner, Radio Speech (April 12, 1937), in Supreme Court Finding Hailed by Wagner as Most Significant Since Marshall, N.Y. TIMES, Apr. 13, 1937, at 20.

2 Joel Rogers \& Wolfgang Streeck, Workplace Representation Overseas: The Works Councils Story, in WORKING UNDER DIFFERENT RULES 97, 98 (Richard B. Freeman, ed., 1994).

${ }^{3}$ See MARK A. ROTHSTEIN, CHARLES B. CRAVER, ELINOR P. SCHROEDER \& ELAINE W. SHOBEN, EMPLOYMENT LAW § 9.1 (3d ed. 2004).

${ }^{4}$ Although Americans enjoy freedom of speech under the First Amendment to the U.S. Constitution, they are only protected against retaliatory state action, not private action. Even public employees enjoy only limited free speech rights. While their governmental employers may not retaliate against them because they have spoken out as private citizens concerning issues of public concern, when they make statements in connection with their official employment duties, they do not enjoy First Amendment protection. See Garcetti v. Ceballos, 547 U.S. 410 (2006).
} 
rights laws that prohibit discrimination based upon race, color, religion, sex, national origin, ${ }^{5}$ age, ${ }^{6}$ or disability. ${ }^{7}$ Most state courts also preclude terminations that would contravene a significant public policy, such as the right to serve on a jury or to refuse to falsify a government-required report. ${ }^{8}$ They enjoy no protection against unjust dismissals, unless they are covered by bargaining agreements that have been negotiated by representative labor organizations. They may similarly be laid off at any time for almost any reason. Only when mass layoffs or plant closures are involved are employers required to provide the adversely affected personnel with sixty days advance notice of such occurrences. ${ }^{9}$

\section{LEGAL SOURCES}

The sole legal right employees have to meaningfully influence their employment conditions is available through union representation. Railroad and airline employees enjoy this right under the Railway Labor Act, ${ }^{10}$ while other private sector workers enjoy that right under the National Labor Relations Act (NLRA). ${ }^{11}$ Under both statutes, employees have the right to support unions, to organize, and to select representative unions for collective bargaining purposes. If a majority of employees in an appropriate

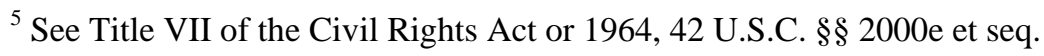

${ }^{6}$ See the Age Discrimination in Employment Act, 29 U.S.C $\S \S 621$ et seq. (prohibiting discrimination against persons forty and older).

${ }^{7}$ See the Americans with Disabilities Act, 42 U.S.C. $\S \S 12101$ et seq.

${ }^{8}$ See ROTHSTEIN, CRAVER, SCHROEDER \& SHOBEN, supra note 3, at §§ 9.9-9.13.

${ }^{9}$ See the Worker Adjustment and Retraining Notification Act, 29 U.S.C. $§ \S 2101$ et seq.

${ }^{10} 45$ U.S.C $\S \S 151$ et seq.

1129 U.S.C. $\S \S 151$ et seq.
} 
bargaining unit designate a particular labor organization as their agent, that union becomes the exclusive bargaining agent for all of the employees in that unit, including individuals who oppose union representation. If no union obtains such majority support, it has no formal rights under U.S. labor law.

A non-majority union may not become the exclusive bargaining agent for a group of workers, but it may bargain for specified employees on a members-only basis - if any employer agrees to such a voluntary arrangement. ${ }^{12}$ It is rare for employers to have any dealings with unions that have not established - either through authorization cards signed by a majority of employees in particular units or through secret ballot elections conducted by the Labor Board - that they enjoy the support of a majority of employees in specified units.

If an exclusive bargaining agent is selected by a majority of employees in an appropriate unit, that entity has the right to negotiate with their employer with respect to their wages, hours, and other terms and conditions of employment. These negotiations may occur at the enterprise level, the plant level, or the shop level, depending upon the structure of the employing firm and the issues to be addressed. The employer is required to bargaining in good faith over such issues, but it is not obliged to make any concessions or to agree to any particular union demands. ${ }^{13}$ If the employer refuses to give in to union demands, the workers may elect to strike, but a struck employer possesses the lawful

\footnotetext{
${ }^{12}$ Although Professor Charles Morris has cogently argued that even non-majority unions have the statutory right to demand bargaining on a members-only basis that would permit them to negotiate on behalf of actual union members without employer consent, it is doubtful the Labor Board or the U.S. Supreme Court would accept this interpretation of the NLRA. See CHARLES J. MORRIS, THE BLUE EAGLE AT WORK (2005).

${ }^{13}$ See 29 U.S.C. § 158(d) (defining the statutory duty to bargain).
} 
right to hire temporary or permanent replacements for the striking workers. ${ }^{14}$

Permanently replaced economic strikers only have to be place on a preferential recall list and be reemployed as future vacancies occur. ${ }^{15}$

Collective bargaining agreements generally define basic employment terms, and provide that employees may not be disciplined except for “just cause.” They also contain grievance-arbitration procedures which allow employees to file grievances challenging particular employer actions and allow unions to invoke binding arbitration procedures when they have been unable to resolve grievances through mutual discussions. The union either designates or a group of workers elect shop stewards who represent the employees at the shop level. Individuals who feel aggrieved by employer actions may file formal grievances and ask their shop stewards to process their claims. Although shop stewards and other union officials - may obtain the information they need to administer the applicable bargaining agreement, they do not possess the right to see general firm financial or managerial information. ${ }^{16}$

Individual members of bargaining units have the statutory right to present personal grievances to their employer for possible resolution without going through their representative union - so long as the labor organization is notified about such discussions and given the opportunity to be present and no personal grievance adjustment is contrary

\footnotetext{
${ }^{14}$ See NLRB v. Mackay Radio \& Telegraph Co., 304 U.S. 333 (1938). See also Trans World Airlines, Inc. v. Independent Federation of Flight Attendants, 489 U.S. 426 (1989).

${ }^{15}$ See Laidlaw Corp., 171 N.L.R.B. 1366 (1968), enforced, 414 F.2d 99 (7 $7^{\text {th }}$ Cir. 1969), cert. denied, 397 U.S. 920 (1970).

${ }^{16}$ See NLRB v. Acme Industrial Co., 385 U.S. 432 (1967) (indicating that representative unions are entitled to the information they need to administer bargaining agreements). Compare NLRB v. Truitt Manufacturing Co., 351 U.S. 149 (1956) (employers not required to provide unions with confidential firm financial information unless they assert an inability to afford union demands during negotiations).
} 
to the terms of the applicable bargaining agreement. ${ }^{17}$ Most bargaining unit members dissatisfied with employer actions challenge those actions through their representative union. They file a grievance with their shop steward who tries to achieve an appropriate resolution with the appropriate lower level supervisor. If no agreement is reached, higher level union and management officials try to reach an agreement. If no settlement is achieved, the union has the right to invoke binding arbitration conducted by an external neutral selected jointly by the disputing parties.

The Railway Labor Act was enacted in 1926 when most railroad workers were already represented by different trade unions. Most other private sector employees were not unionized at that time. The American Federation of Labor (AFL) had been formed in 1886, consisting primarily of craft unions that represented different skilled trades. When the NLRA was passed in 1935, the U.S. was in a transition from an agricultural economy to an industrial economy. When it became clear that traditional AFL craft unions would find it difficult to organize the skilled, semi-skilled, and unskilled persons working in manufacturing, the Congress of Industrial Organizations (CIO) was formed and new industrial unions were created to organize the automobile, steel, rubber, and electrical manufacturing firms. By the mid-1950s, thirty-five percent of private sector workers were members of labor organizations. ${ }^{18}$ At the same time, the AFL and CIO combined to form the AFL-CIO, and competition between AFL craft unions and CIO industrial unions ceased.

\footnotetext{
${ }^{17}$ See 29 U.S.C. § 159(a).

${ }^{18}$ See MICHAEL GOLDFIELD, THE DECLINE OF ORGANIZED LABOR IN THE UNITED STATES 10, Table 1 (1987). See generally CHARLES B. CRAVER, CAN UNIONS SURVICE? (1993).
} 
American labor organizations had successfully represented millions of workers for whom they enhanced their wages, fringe benefits, and general employment conditions. They created a true middle class for many blue collar employees. Although unionized companies tended to have greater productivity than nonunion firms, the wage premium generated by the bargaining process diminished the overall profits earned by organized corporations. The accommodation that had existed between labor and management during the 1950s and 1960s began to deteriorate due in part to the elevated inflation during the latter part of the 1970s which caused wages to rise substantially for unionized workers covered by cost-of-living-adjustment clauses which rose with increases in the consumer price index. Labor-management relations also declined in the latter part of the 1970s, after the business community worked successfully to defeat relatively modest labor law reform proposals that had been sought by union supporters.

By 1980, the percentage of private sector workers who were union members had declined to twenty-three percent. That decline was further exacerbated by globalization and the transfer of millions of production jobs to lower cost countries like Mexico and China, and the shift in the U.S. from a manufacturing economy to a white-collar, professional, and service economy - sections which unions found difficult to organize. By the end of 2010, only 6.9 percent of private sector employees were union members. ${ }^{19}$ This means that the vast majority of employees no longer have a collective voice vis-avis their corporate employers.

\footnotetext{
${ }^{19}$ See Daily Labor Report (B.N.A.). No. 14 (Jan. 21, 2011), at AA-1. It is interesting to note that during the continued decline in private sector union membership, the percentage of public sector employees in labor organizations remained relatively constant at approximately thirty-six percent. This private-public sector disparity is partially due to the absence of a profit motive by governmental employers who do not work hard to discourage unionization by their workers.
} 
As labor organizations have declined, their absence has been filled by legislative regulations and expanded judicial involvement as workers have sought protection against the types of issues previously addressed in bargaining agreements and enforced through internal grievance-arbitration procedures. A brief review of some of the more significant legislative developments demonstrates the impact of proliferating legislative rules. The Equal Pay Act of $1963^{20}$ prohibits compensation differentials between male and female employees performing equal work. Title VII of the Civil Rights Act of $1964^{21}$ proscribes all employment discrimination based upon race, color, religion, sex, or national origin. The Age Discrimination in Employment Act of $1967^{22}$ bans discrimination against individuals forty years of age or older. The Pregnancy Discrimination Amendment of $1978^{23}$ extends the Title VII prohibition against gender discrimination to distinctions based upon pregnancy, childbirth, and related medical conditions. The Occupational Safety and health Act of $1970^{24}$ requires employers to provide workers with safe employment environments, with Occupational Safety and Health Administration regulations setting standards which specify the exact conditions that must be provided, even if alternative measures might equally protect employee interests. The Employee Retirement Income Security Act of $1974^{25}$ prescribes minimum vesting rules for private sector pension programs, establishes prudent investor obligations for pension funds, and

\footnotetext{
${ }^{20}$ Pub. Law No. 88-38, codified at 29 U.S.C. § 206(d).

${ }^{21}$ Pub. Law No. 88-352, codified at 42 U.S.C. §§ 2000e et seq.

${ }^{22}$ Pub. Law No. 90-202, codified at 29 U.S.C. §§ 621 et seq.

${ }^{23}$ Pub. Law No. 95-555, codified at 42 U.S.C. $§ 2000 \mathrm{e}(\mathrm{k})$.

${ }^{24}$ Pub. Law No. 91-596, codified at 29 U.S.C. $§ \S 651$ et seq.

${ }^{25}$ Pub. Law No. 93-406, codified at 29 U.S.C. §§ 1001 et seq.
} 
creates mandatory standards with respect to other fringe benefit programs. The Worker Adjustment and Retraining Notification Act of $1988^{26}$ requires sixty days advance notice of mass layoffs and plant closures, and the Drug Free Workplace Act of $1988^{27}$ obliges employers to take steps to minimize illegal drug usage among employees. The Employee Polygraph Protection Act of $1988^{28}$ outlaws the use of lie detectors by private employers except in narrowly prescribed circumstances. Title I of the Americans with Disabilities Act of $1990^{29}$ prohibits employment discrimination against qualified individuals with mental or physical disabilities and obliges employers to provide reasonable accommodations for disabled persons if they can be furnished without undue hardship to employers. The Family and Medical Leave Act of $1993^{30}$ mandates unpaid leave for workers affected by childbirth and family medical difficulties.

Judicial intervention over the past three decades has similarly restricted managerial freedom with respect to employee terminations. As courts encountered shocking cases of wrongful discharges, judges began to create exceptions to the traditional employment-at-will doctrine. ${ }^{31}$ Most state courts have recognized an exception that precludes the termination of workers based upon grounds that contravene important public policies. Courts have increasingly held employers liable for discharges that violate express or implied contractual limitations set forth in personnel policies or

\footnotetext{
${ }^{26}$ Pub. Law No. 100-379, codified at 29 U.S.C. §§ 2101 et seq.

${ }^{27}$ Pub. Law No. 100-690, codified at 41 U.S.C. $§ \S 701$ et seq.

${ }^{28}$ Pub. Law No. 100-347, codified at 29 U.S.C. §§ 2001 et seq.

${ }^{29}$ Pub. Law No. 101-336, codified at 42 U.S.C. §§ 12111 et seq.

${ }^{30}$ Pub. Law No. 103-3, codified at 29 U.S.C. $\S \S 2601$ et seq.

${ }^{31}$ see generally ROTHSTEIN, CRAVER, SCHROEDER \& SHOBEN, supra note 3, at §§ 9.1-9.25.
} 
employee performance review procedures.. A few state courts have even found implied covenants of good faith and fair dealing in individual employment contracts. Future judicial developments will likely erode employer freedom to a greater degree in this critical area.

Professors Richard Freeman and Joel Rogers conducted a survey of over 2400 persons and found that eighty-seven percent of U.S. workers would like some work place institution that would represent their interests. ${ }^{32}$ About half would like an organization strongly independent from their employer, with the other half leaning toward an institution that would be somewhat independent from management. The workers supporting such arrangements thought that employees would enjoy their jobs more if decisions regarding production and operations were made jointly by workers and management instead of by management alone, and they though that their firms would be more competitive if such employee-employer consultation systems existed. ${ }^{33}$ Many of the respondents indicated that a major reason for their hesitancy to seek a collective voice concerned fears of employer retribution if they did so. Although it is unlawful for employers to retaliate against employees because of their exercise of protected rights under the NLRA, ${ }^{34}$ it usually takes a year or two for illegally terminated individuals to obtain reinstatement orders, and the only monetary cost to the responsible employers, beyond their own attorney fees, involves back pay for the persons who have been out of work. By the time many illegally discharged employees obtain offers of reinstatement,

\footnotetext{
${ }^{32}$ See RICHARD B. FREEMAN \& JOEL ROGERS, WHAT WORKERS WANT 147, Exhibit 7.2 (1999).

${ }^{33}$ See id. at 42.

${ }^{34}$ See 29 U.S.C. § 158(a)(3) (prohibiting employer discrimination against employees who have exercised rights protected under the NLRA).
} 
they have found positions with other firms and they decline the chance to return to their former places of employment. Unions find it especially difficult to win Labor Board representation elections following the discharge of open employee organizers.

The ninety-two percent of private sector workers who do not have union representation have no legal right to participate in the operational management of their employers. They are employed on an at-will basis, and are subject to termination at any time for almost any reason. If an informal group of employees were to get together to discuss specific employment issues with their employer, they would be engaged in “concerted activities for ... mutual aid or protection” within the meaning of Section 7 of the NLRA ${ }^{35}$ and be protected against retaliatory actions. On the other hand, if individual employees were to try to influence firm decisions affecting employment conditions, they would not be engaged in protected concerted conduct - unless they were acting on behalf of other employees or were seeking to induce other workers to support their actions.

Although most nonunion U.S. employers wish to remain unorganized, many have begun to appreciate the gains that may be achieved through limited worker participation programs. They have thus formed committees consisting of rank-and-file employees and management personnel that are designed to focus on issues such as productivity and service quality. Most of these employers participate directly in the selection of the employees to serve on these committees, and they generally determine the limited issues to be addressed.

Although these firm-generated worker participation programs have become relatively common with respect to nonunion employers, many are technically unlawful

\footnotetext{
${ }^{35}$ See 29 U.S.C. $§ 157$.
} 
under the NLRA. Section 2(5) expansively defines the term "labor organization" to include any "employee representation committee or plan, in which employees participate and which exists for the purpose, in whole or in part, of dealing with employers concerning grievances, labor disputes, wages, rates of pay, hours of employment, or conditions of work." ${ }^{36}$ Section 8(a)(2) of the same statute makes it an unfair labor practice for an employer "to dominate or interfere with the formation or administration of any labor organization., ${ }^{37}$

In a series of decisions, the Labor Board has technically limited the ability of nonunion employers to establish and maintain worker participation committees. ${ }^{38}$ The Board must initially determine whether the entity created by the employer constitutes a "labor organization" within the meaning of Section 2(5). A "labor organization” will be found if the participation committee in question consists in whole or in part of employees who act in a representational capacity by purporting to speak on behalf of other workers, and if it "deals with" the employer with respect to wages, hours, or working conditions. If the employer merely solicits input from such a committee and then decides on its own what to do, the committee would not be "dealing with" management. ${ }^{39}$ On the other hand, if managers and employee committee members discuss various proposals and the employee members influence final firm decisions, the committee would be "dealing

\footnotetext{
${ }^{36} 29$ U.S.C. § 152(5).

${ }^{37} 29$ U.S.C. § 158(a)(2).

${ }^{38}$ See Electromation, Inc., 309 N.L.R.B. 990 (1992), affirmed, 35 F.3d 1148 (7 $7^{\text {th }}$ Cir. 1994); Keeler Brass Automotive Group, 317 N.L.R.B. 1110 (1995); Crown Cook \& Seal Co., 334 N.L.R.B. 699 (2001).

${ }^{39}$ See, e.g., NLRB v. Peninsula General Hospital, 36 F.3d 1262 (4 ${ }^{\text {th }}$ Cir. 1994).
} 
with" the employer. ${ }^{40}$ Since most of the worker participation committees that have been established by employers to speak for other employees and do "deal with” management with respect to employment conditions, they are legally "labor organizations" under the NLRA.

If worker participation committees are determined to be "labor organizations," the Labor Board must then decide whether the employer unlawfully dominates or interferes with the formation or administration of those entities. If the employer selects the employee committee members or controls the nomination and election process for employee members, unlawful domination will be found with respect to the formation of these groups. Even if the employer permits the employees to nominate and elect their own committee members, if the employer controls the agenda of committee meetings and controls the topics to be discussed, unlawful domination of the administration of those committees is likely to be found.

Although some parties have challenged the legality of employer-established worker participation committees, most committees have gone unchallenged. Few employees are aware of their NLRA rights, and employers are not required to apprise them of their rights under that statute. As a result, most employees participating in or affected by such worker participation programs do not realize that the operation of those entities may contravene the NLRA. In addition, where such committees have worked well and the employees feel satisfied with the way in which their employers have dealt with these institutions, the employees would be unlikely to challenge their existence. Many workers are pleased that such entities exist, and they wish these committees

\footnotetext{
${ }^{40}$ See, e.g., Keeler Brass Automotive Group, 317 N.L.R.B. 1110 (1995).
} 
possessed greater authority and could consider more than productivity and quality issues. Such committees are most likely to be challenged legally only when outside unions decide to organize the employees affected by them and they want to deprive the target employers of the ability to use such worker participation programs as a means to convince the employees that they do not need representation by outside labor organizations.

In the late 1990s, employers sought the enactment of the Teamwork for Employees and Managers Act which would have provided companies with greater freedom with respect to the operation of worker participation programs. Although the TEAM Act passed the House of Representatives and the Senate, it was vetoed by President Clinton. ${ }^{41}$ Despite the election of a more conservative President Bush in 2000, the business community did not work to get the TEAM Act through another congress. Their existing worker participation programs were functioning well and with few legal challenges, and it no longer seemed important to change the existing law regulating this area.

It is ironic in the U.S. that nonunion workers are provided with no statutory right to participate in firm operations at the plant level - and that employer efforts to create meaningful worker participation programs are likely to be unlawful if committee members act in a representative capacity and “deal with" their employer in any significant manner with respect to wages or working conditions.

\section{FEATURES OF EMPLOYER-ESTABLISHED WORKER COMMITTEES}

\footnotetext{
${ }^{41}$ See Daily Labor Report (B.N.A.) No. 147 (July 31, 1996) at AA-1.
} 
Even though the U.S. has no rules requiring worker participation at the plant level and even though the establishment of employee representation committees by employers is likely to contravene the NLRA due to the extensive control firms exercise over their creation and administration, thousands of businesses have created such committees. They rarely do so to advance worker interests, but rather to enhance firm profitability. Some are limited to health and safety issues to minimize firm liability under state and federal occupational safety and health laws. Most, however, are used primarily to enhance worker productivity and product or service quality. Employers appreciate the fact that employees often know how to make their jobs more efficient and how to improve the quality of what they produce.

Some employers try to avoid layoffs that might be generated by greater individual productivity, and they even discuss gain-sharing with the employee committees to reward workers for their increased outputs. Nonetheless, other firms do not hesitate to lay off redundant personnel and retain all of the increased earnings for managers and shareholders. ${ }^{42}$ It is experiences like those emanating from these latter companies that make employees skeptical about the benefits they are likely to derive from worker participation committee efforts.

Most of these committees consist of rank-and-file employees and management personnel. In some cases, the employer selects the individuals to serve, while in others the workers are allowed to select their own representatives. The agendas of worker participation committees are generally determined by employer officials. They tend to focus on the issues they consider important to firm success. Nonetheless, some firms take

\footnotetext{
${ }^{42}$ See Charles B. Craver, The American Worker: Junior Partner in Success and Senior Partner in Failure, 37 UNIVERSITY OF SAN FRANCISCO LAW REVIEW 587 (2003).
} 
a more expansive approach and permit such issues as employee discipline to be considered. Some allow employee representatives to bring up issues they think workers would like to have discussed.

More expansive worker participation committee agendas can have beneficial results for both employees and employers. Rank-and-file workers usually know their jobs well, and they are able, if asked, to suggest ways to improve productivity and quality. So long as they do not fear job losses due to their good faith efforts to enhance firm profitability, they are likely to participate meaningfully and feel appreciated by corporate managers.

\section{POSSIBILITY OF MANDATED WORKER PARTICIPATION}

Unless the American labor movement is able to drastically reverse the downward trend which has existed over the past fifty years, it is unlikely that we will see significant union growth in the coming years. The heavily organized production industries are being replaced by white-collar, professional, and service firms in retail, finance, health care, insurance, and similar areas. Even inventive unions like the Service Employees International Union (SEIU) find it difficult to generate support among employees at firms like Wal-Mart.

If the eighty-seven percent of employees who wish to have a collective voice at work are to be heard, some form of statutorily prescribed plant level program will be necessary. European nations - both under individual statutes and European Union directives - provide far more expansive shop level worker participation. ${ }^{43}$ Either employers must be required to establish works council type institutions, or employees

\footnotetext{
${ }^{43}$ See generally JOEL ROGERS \& WOLFGANG STREECK, eds., WORKS COUNCILS (1995).
} 
must be authorized to request the creation of such entities. Firms with worker

participation committees would be obliged to provide such institutions with firm information regarding firm operations and contemplated managerial changes that would significantly affect employee interests. At a minimum, firms should have to consult with employee participation committees before they implement such changes, and, in some cases, more significant steps could be required under codetermination-like procedures that would allow such committees to block proposed management actions.

The U.S. is not currently ready for such expansive worker participation either economically or politically. American business leaders believe that the creation of European style worker participation programs would greatly diminish productivity and efficiency. Due to the history of adversarial labor-management relations, managers fear that some employee representatives on participation committees would view management as the enemy. These representatives would be suspicious of firm proposals that are reasonably calculated to enhance firm operations to the benefit of both shareholders and workers. Managers are also concerned about the fact that rank-and-file employees who have absolutely no managerial experience will not appreciate why certain operational decisions must be made.

If meaningful shop level worker participation is to occur, Congress would have to enact a statute requiring all firms with a minimum number of fifty, one hundred, or two hundred employees to create worker participation committees. ${ }^{44}$ For smaller firms with a single location, one committee would be sufficient. For larger firms, with different

\footnotetext{
${ }^{44}$ See Charles B. Craver, Mandatory Worker Participation is Required in a Declining Union Environment to Provide Employees with Meaningful Industrial Democracy, 66 GEORGE WASHINGTON LAW REVIEW 135 (1997). See also Stephen Befort, A New Voice for the Workplace: A Proposal for an American Works Councils Act, 69 MISSOURI LAW REVIEW 607 (2004).
} 
divisions at the same location, separate committees might be required for each department. Where multi-plant operations are involved, at least one worker committee would be required for each facility that had more than a specified minimum number of employees. Larger corporations could be required to establish enterprise level participation committees that would have to be consulted when issues of firm-wide significance are being contemplated.

The law could require that two-thirds or three-quarters of committee members be elected by rank-and-file employees, with the other one-third or one-quarter being elected by lower level management personnel who often think that their voices are not being heard by higher management officials. Committee members could serve four year terms, with half being elected every two years to provide some continuity. Term limits could be imposed to insure that the same individuals would not serve for prolonged periods. If enterprise level participation committees were established, the members of such firmwide committees could be elected by local worker participation committees. ${ }^{45}$

Although employers have generally opposed legislation that would grant employees the right to participate directly in managerial decisions, two factors might ultimately persuade them that such programs would not necessarily have negative consequences. First, if unions use the Internet to reach employees whose employers have established internal worker participation programs designed merely to improve productivity and quality, with minimal benefit to the affected employees, more unfair

\footnotetext{
${ }^{45}$ Rank-and-file employees and lower level managerial personnel could also be allowed to elect several corporate board members to allow them to express worker interests at board meetings, with all board members having dual fiduciary obligations to both workers and shareholders. Where shareholder and worker interests conflict, board members could be immune from liability so long as they make good faith decisions that reasonably consider shareholder and employee interests.
} 
labor practice cases will be prosecuted before the Labor Board at substantial cost to firms. Second, if most businesses remain unorganized when eighty-seven percent of workers wish to have some collective voice, more employees may contemplate unionization and many will seek greater legislative involvement at the federal and state levels designed to further restrict managerial freedom. In addition, more wrongful law suits will be filed which will cost employers millions of dollars.

Employer representatives regularly complain about the increasing legislative and judicial regulation of employment relationships. They assert that the inappropriate behavior of a few aberrant companies has generated restrictive federal and state rules that unreasonably limit the managerial freedom of mainstream firms. They also maintain that rational employers do not overtly discriminate or make personnel decisions based upon improper considerations, noting that such conduct would be economically inefficient. The cost of replacing skilled employees who possess firm-specific training is so high that corporate leaders would not unnecessarily sever beneficial employment relationships and risk placing their firms at a competitive disadvantage.

American business officials maintain that human capital is their most important resource, and they claim they treat their workers fairly and generously. To enhance employer-employee relations, many companies have created shop level employee participation committees. These programs may be called “quality circles,” “production teams," or "quality of work life programs.” These arrangements are designed to facilitate communication between managers and employees, to improve product or service quality, and to increase worker productivity. 
When the legal status of many firm-established worker participation programs has been challenged, the Labor Board has held that such institutions constitute "labor organizations” that are unlawfully dominated by the employers that established them and that control their operations. To counteract these Board decisions, corporate leaders sought the enactment of the Teamwork for Employees and Managers Act which would have provided companies with greater freedom in this area.

Business leaders believe that companies need worker participation programs to increase worker-management communication and to enhance employee productivity and output quality. They recognize that firms in countries like Germany and Japan have used employee involvement committees to improve their competitive positions in global markets, and would like to achieve similar benefits in the U.S. ${ }^{46}$

Corporate executives frequently complain about the lack of employee commitment to firm objectives. They cannot understand why their workers do not share their institutional enthusiasm. They ignore the fact that they have specifically told new employees that their positions can be terminated at any time for any reason. They fail to appreciate the fact that these employment-at-will relationships and lack of worker involvement in the managerial decision-making process generate employee insecurity. ${ }^{47}$ Employees reasonably fear that suggested productivity enhancements will be rewarded not by greater firm appreciation, but by layoffs caused by the need for fewer workers. ${ }^{48}$

\footnotetext{
${ }^{46}$ See Marleen A. O’Connor, The Human Capital Era: Reconceptualizing Corporate Law to Facilitate Labor-Management Cooperation, 78 CORNELL LAW REVIEW 899, 936-940 (1993).

${ }^{47}$ See LESTER THUROW, HEAD TO HEAD 137-140 (1992).

${ }^{48}$ See Aleta G.Estreicher, Beyond Agency Costs: Managing the Corporation for the Long Term, 45 RUTGERS LAW REWIEW 513, 575-579 (1993) (discussing the treatment of labor in the U.S.).
} 
Employees also believe that quality improvements will increase shareholder equity and managerial bonuses, but not be shared with regular workers. ${ }^{49}$

If corporate officials wish to improve employee morale, avoid the further proliferating of intrusive federal and state intervention, and retain greater localized control over their terms and conditions of employment, they should appreciate the potential benefits to be derived from truly reciprocal worker participation programs. Such programs would provide employees with a greater appreciation for the competitive pressures affecting their employers, and business firms would obtain valuable input from their knowledgeable workers. Federal legislation could authorize employee involvement committees to oversee the enforcement of safety and health regulations, wage and hour laws, civil rights enactments, and other similar employment legislation. When warranted, such committees could grant employers waivers from unnecessary federal and state regulations, so long as these waivers did not compromise underlying worker interests. If they were to function efficiently, cooperative employer-employee involvement programs could replace traditionally adversarial labor-management relationships.

It is time to acknowledge that corporate success is dependent upon three symbiotic groups: (1) the investors who provide the necessary capital; (2) the mangers who provide the requisite leadership; and (3) the employees who perform the basic job functions. Corporate laws protect the rights of business investors. Federal and state securities laws entitle prospective shareholders to receive extensive firm information before they decide whether to purchase shares of stock. Shareholders receive extensive

\footnotetext{
${ }^{49}$ See Marleen A. O’Connor, Restructuring the Corporation's Nexus of Contracts: Recognizing a Fiduciary Duty to Protect Displaced Workers, 69 NORTH CAROLINA LAW REVIEW 1189, 1210 (1991).
} 
information regarding firm operations, and they directly participate in the election of corporate directors. Firm managers owe shareholders a fiduciary duty and are liable to stockholders who are injured by breaches of this duty. In addition, because capital is a highly mobile commodity, shareholders can protect their interests through diversification and by transferring their financial support from poorly performing businesses to other investments.

Corporate managers possess the capacity to protect themselves against business vicissitudes. They enjoy access to confidential information regarding firm performance, and they exercise meaningful discretion over decisions that affect their own futures. They can usually avoid the insecurity associated with employment-at-will arrangements through individual employment contracts that guarantee their continued employment for specified terms. They may be able to obtain generous severance packages if they lose their positions through corporate reorganizations or buyouts. They often benefit from bonus payments and stock options that are unavailable to most subordinate personnel.

Rank-and-file employees are generally treated no better than the equipment they use or operate. ${ }^{50}$ Even though such employees commit their working lives to the success of their respective firms, they enjoy no employment security. They are not privy to confidential firm information, nor are they usually consulted about business decisions that may directly affect their employment destinies. Most lack the unique personal skills required to provide them with significant career mobility.

\footnotetext{
${ }^{50}$ See CHARLES A. REICH, OPPOSING THE SYSTEM 22 (1995).
} 
American employees are feeling increasingly isolated and underappreciated. ${ }^{51}$ Most would like the opportunity to be part of larger employment communities in which they could openly share their ideas and concerns with their colleagues. ${ }^{52}$ They want to be respected for their knowledge and be trusted to perform their job tasks even if management officials are not closely monitoring them. Their objectives can only be achieved if Congress enacts legislation that requires larger employers to provide their employees with meaningful shop level participation.

\section{SUMMARY}

The U.S. has no formal rules requiring worker participation at the shop level. Where employees have selected labor organizations as their bargaining agents, they are able through such unions to influence their wages, hours, and working conditions both at the enterprise level and the shop level. Such bargaining relationships were quite common throughout the 1950s, 1960s, and 1970s, when twenty-five to thirty-five percent of private sector workers were union members. As a result of globalization, transition from an industrial to a white-collar and service economy, and increased employer opposition to labor organizations, the percentage of private sector workers in unions has declined to 7.5 percent. As this downward trend has occurred, federal and state legislatures have filled the void with the enactment of many statutes restricting managerial freedom. Judicial decisions have eroded the traditional employment-at-will rule allowing employers to terminate employees at any time for almost any reason.

\footnotetext{
${ }^{51}$ See Thomas C. Kohler, Individualism and Communitarianism at Work, 1993 BRIGHAM YOUNG UNIVERSTIY LAW REVIEW 727 (1993); Robert D.Putnam, Bowling Alone: America's Declining Social Capital, 6 JOURNAL OF DEMOCRACY 65, 68-69 (1995).

52 See RICHARD B. FREEMAN \& JOEL ROGERS, WORKER REPRESENTATION AND PARTICIPATION SURVEY: REPORT OF THE FINDINGS 14-17 (Princeton University Associates 1994).
} 
A number of employers have established their own employee committees primarily to enhance product or service quality and to improve productivity. Many of these institutions constitute "labor organizations" within the meaning of the NLRA and are actually unlawful if the employers control the selection of employee members or the issues to be addressed.

If the ninety-two percent of U.S. workers with no union representation hope to obtain plant level participation, Congress will have to enact a law mandating employee participation committees. If these committees could generate cooperative workermanagement relationships, they could diminish legislative involvement in employment, and even provide employers with a way to oversee the enforcement of many existing employment laws. 